Abstract 1349 Table 1

\begin{tabular}{|c|c|c|}
\hline & $\begin{array}{l}\text { Treatment with Abidec } \\
\text { Median (range) }\end{array}$ & $\begin{array}{l}\text { Treatment with } \\
\text { Cholecalciferol Median (range) }\end{array}$ \\
\hline Birth Weight (kilogram) & $3.26(2.25-5.01)$ & $3.27(1.94-4.72)$ \\
\hline Gestaional Age (weeks) & $39.5(36-42)$ & $40(36-43)$ \\
\hline Initial Vitamin D levels (ng/dl) & $14.9(3.1-54)$ & $12.8(1.3-69.8)$ \\
\hline Post Treatment Vitamin D levels & $32.2(11.6-44.1)$ & $40.6(26.3-8-0.2)$ \\
\hline $\begin{array}{l}\text { Time from birth to initial } \\
\text { Vitamin D levels (days) }\end{array}$ & $1(0-69)$ & $2(0-38)$ \\
\hline $\begin{array}{l}\text { Time between initial and post } \\
\text { treatment Vitamin D levels (days) }\end{array}$ & $49(37-122)$ & $77(18-266)$ \\
\hline
\end{tabular}

Conclusions Abidec alone is effective treatment for infants with maternal vitamin $\mathrm{D}$ deficiency.

\section{LOW 25-HYDROXYVITAMIN D LEVEL AND ADIPONECTIN IS ASSOCIATED WITH INSULIN SENSITIVITY IN LARGE GESTATIONAL AGE INFANTS}

doi:10.1136/archdischild-2012-302724.1350

${ }^{1} \mathrm{~F}$ Cekmez, ${ }^{2} \mathrm{G}$ Aydemir, 'S Aydınoz, ' 0 Pirgon, ' $\mathrm{FA}$ Genc, ${ }^{1} \mathrm{~T}$ Tunc, ${ }^{1} \mathrm{SU}$ Sarici. ' $G u ̈ l h a n e$ Askeri Tip Akademisi, Ankara; 'ATA Haydarpasa Teaching Hospital, Istanbul, Turkey

Objective To investigate the relationship between adipokines (visfatin, adiponectin) and 25-hydroxyvitamin $\mathrm{D}(25(\mathrm{OH}) \mathrm{D})$, and markers of insulin sensitivity in large for gestational age (LGA) infants.

Patients and Methods Forty LGA infants (25 LGA born to diabetic mothers and 15 LGA born to non-diabetic mothers) and 34 appropriate for gestational age (AGA) infants were recruited.

Results FGIR, QUICK-I, adiponectin and 25(OH)D levels were significantly lower in LGA with diabetic mother group than AGA and LGA with non-diabetic mother group. HOMA-IR, fasting insulin, visfatin and parathormone (PTH) levels levels were significantly higher in LGA with diabetic mother group than AGA and LGA with non-diabetic mother group.

Conclusion Based on the findings of this study, visfatin, adiponectin and 25(OH)D levels can be used as specific markers for insulin sensitivity and may help advance new therapies for glucose intolerance spectrum.

\section{OSTEOPENIA IN HIGH RISK PRETERM POPULATION IN MANITOBA: A CASE-CONTROL STUDY}

doi:10.1136/archdischild-2012-302724.1351

${ }^{1,2} \mathrm{H}$ Soylu, 'E Ali, ${ }^{3} \mathrm{M}$ Reed, 'S Fast, 'SE Moisiuk, 'MM Seshia. 'Neonatology/Pediatrics, ${ }^{2}$ Pharmacology \& Therapeutics; ${ }^{3}$ Radiology, University of Manitoba, Winnipeg, MB, Canada

Background Despite recent advances in care of VLBW infants, osteopenia of prematurity (OP) remains an important problem in most NICUs.

Objective To compare demographic, perinatal and postnatal characteristics of OP in VLBW babies admitted to our Level III NICU, to elucidate risk factors and association of biochemical bone markers with radiological changes and the clinical outcome.

Design/methods Infants born $\leq 29$ weeks GA and admitted between October 2007 to January 2011. Only those infants with both chest X-rays and biochemical markers at or beyond 6 weeks post natal age were included. Infants were grouped as cases and controls based on serum Ca, P, ALP and X-ray findings and were stratified by GA: 24-25, 26-27 and 28-29 weeks. X-ray findings and biochemical results were considered in 2 week periods.
Results Of 176 potentially eligible infants 54 (GA $26.9 \pm 0.2$ wks, BW $970 \pm 34 \mathrm{~g}$ ) met the criteria for inclusion. $26 \%$ of the cases vs. $3 \%$ of the controls were from communities north of the $55^{\circ}$ latitude $(\mathrm{p}<0.05)$. Serum Ca levels were within the normal range, but serum $\mathrm{P}$ levels were subnormal. The most significant biochemical discriminator between the two groups was the serum ALP level.

\begin{tabular}{|c|c|c|c|c|c|c|}
\hline & \multicolumn{2}{|c|}{$24.25 \mathrm{GA}$} & \multicolumn{2}{|c|}{$26-27 \mathrm{GA}$} & \multicolumn{2}{|c|}{$28-29 \mathrm{GA}$} \\
\hline & $\begin{array}{l}\text { Cases } \\
(a ; 6)\end{array}$ & $\begin{array}{c}\text { Controls } \\
(a: 6)\end{array}$ & $\begin{array}{l}\text { Caves } \\
(\mathrm{n}: 10)\end{array}$ & $\begin{array}{l}\text { Controls } \\
\text { (a:14) }\end{array}$ & $\begin{array}{l}\text { Cases } \\
\text { (n:7) }\end{array}$ & $\begin{array}{l}\text { Controls } \\
\text { (a:11) }\end{array}$ \\
\hline Gestatiodal age (wk) & $248+02$ & $25=0.1$ & $263=01$ & $26.7=02$ & $287 \pm 02$ & $286 \div 02$ \\
\hline Birth wcight (e) & $818+49$ & $793+42$ & $918+87$ & $94-39$ & $1023+132$ & $1194+72$ \\
\hline Mech. Vent. (d) & 50.6 & 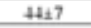 & $26=4$ & $2 \operatorname{se} x$ & $17 \pm 3$ & 1624 \\
\hline CPAPSNasal now(d) & $119 \pm 15$ & $119 \pm 11$ & $10 x=14$ & $83 \pm 12$ & $67 \pm 13$ & $75 \pm 10$ \\
\hline Ca (mmelli) & 234003 & 2.34006 & 234004 & $2.27 \pm 004$ & $224 \div 005$ & 23.3004 \\
\hline$P(\operatorname{mea} a l / L)$ & 17.005 & 1.840006 & $1.7 \Delta 005$ & 1.761004 & $164100 x^{\circ}$ & $1 \times 22004$ \\
\hline ALP (ILIL) & $H 0=21^{* *}$ & $308 \pm 17$ & $40 \varepsilon_{2}=22^{n+1}$ & $287=12$ & $3900+33 * 0$ & $285 \div 16$ \\
\hline Albumin $(g / L)$ & $2+3=0 \times$ & $24.9 \pm 1$ & $24.9 \pm 0.7$ & $26 x=07$ & $23.4=0.94$ & 262009 \\
\hline
\end{tabular}

Conclusions Our results suggest that geographic factors may be a surrogate marker for maternal factors contributing to the etiology of OP. Future prospective studies may be helpful to define this. Biochemical markers, excepting ALP, are not predictive for OP diagnosis

\section{SURVEY OF MANAGEMENT OF NEONATAL HYPERGLYCAEMIA IN LEVEL 3 NEONATAL UNITS IN UK}

doi:10.1136/archdischild-2012-302724.1352

${ }^{1} \mathrm{~A}$ Gupta, ${ }^{2} \mathrm{~A}$ Lakshmanan, ${ }^{1} \mathrm{C}$ Harikumar, 'S Janakiraman. 'Department of Paediatrics, University Hospital of North Tees, Stockton-on-Tees; '2Department of Paediatrics, Addenbrookes Hospital, Cambridge, UK

Introduction and aim: Hyperglycaemia in preterm babies is a common problem. It is known to be associated with an increased risk of morbidity and mortality, especially in extreme preterm babies. Despite this, there is little established consensus of management. Nonetheless, practice is improving as the neonatal units develop local guidelines on the basis of the limited available research. Currently we don't know the specifics of the prevailing practice, and this is the first needed step in order to carry out any substantial further research.

We carried out the survey to study the prevailing practice in level $3 /$ tertiary units in the United Kingdom.

Methods We collated a list of level 3 units from the British Association of Perinatal Medicine (BAPM) website. We sent an online questionnaire to the Neonatal Consultant. We followed up with a phone call to get more responses.

Results We received responses from 51 units (81\%). It showed that the $80 \%$ of units either follow local or regional guidelines and the majority (78.4\%) now use gas machine for measuring blood glucose We found there is quite a variation in definition of hyperglycaemia, modalities of management, insulin regimen and the endpoint of treatment.

Conclusions Management of neonatal hyperglycaemia is very unit dependant. We agree with other experts that large randomised trials in hyperglycaemic VLBW neonates that are powered on clinical outcomes are needed to determine whether and how the hyperglycaemia should be treated.

\section{INSULIN-TREATED HYPERGLYCAEMIA IS ASSOCIATED WITH LOWER AMINO ACID LEVELS IN VERY PRETERM INFANTS RECEIVING PARENTERAL NUTRITION}

doi:10.1136/archdischild-2012-302724.1353 